\title{
Alkilresorsinoller ve Kanser
}

\section{Alkylresorcinols and Cancer}

\author{
Nursel Şahin ${ }^{1}$, Gamze Akbulut ${ }^{2}$
}

Geliş tarihi/Received: 10.06.2021 • Kabul tarihi/Accepted: 05.12.2021

\section{ÖZET}

Tam tahıllı besinler, bileşiminde bulunan diyet posası, mineraller, vitaminler ve fitokimyasallar nedeniyle sağllğ̆ koruyucu etkilere sahip besinler olarak kabul edilmektedir. Tam tahılların yapısında bulunan ve amfifilik bir fenolik lipit olan alkilresorsinol bileşikleri ise son ylllarda üzerinde durulan bir konu olmuştur. Özellikle in vitro çalışmalarda alkilresorsinollerin antimikrobiyal, antioksidan, membran fosfolipit aktivitesini ve enzim aktivitesini etkileme ve tümörogenezi inhibe etme gibi çeşitli fizyolojik ve biyolojik aktivitelere sahip olduğu belirtilmektedir. Alkilresorsinollerin yapısında bulunan fenolik halka ve alkil zincirinin, insan kanser hücrelerinin çoğalmasının engellenmesi açısından önemli olduğu belirtilmektedir. Yapılan çalışmalarda, alkilresorsinollerin bazı enzimlerin inhibisyonunu ve genotoksisiteyi etkileme, antioksidan aktivite ve kanser hücre hatları üzerinde sitotoksik etki gösterme yeteneği ile kanser patogenezinde önemli bir rolünün olabileceği görülmüştür. Yüksek konsantrasyonlu alkilresorsinollerin insan kolon, meme, akciğer, over, prostat ve hepatik kanser hücre hatlarının inhibisyonunu sağladığı ve bu kanser türleri için yüksek sitotoksik ajanlar olarak kabul edildiği belirtilmektedir. Ayrıca alkilresorsinollerin cinsiyet hormonu sentezini etkileyerek testesteron ve östradiole bağımlı kanserlerin önlenmesinde önemli bir mekanizmaya sahip olduğu düşünülmektedir. Ancak alkilresorsinollerin kanser riski ile ilişkisi hakkında yeterli kanıt bulunmamaktadır. Gelecekte yapılacak çalışmalar ile alkilresorsinoller için güvenli konsantrasyonlar ve kabul edilebilir günlük alım miktarları oluşturulması daha net bilgiler sağlayacaktır. Bununla birlikte, alkilresorsinollerin kanser gelişimindeki potansiyel rolü, tam tahıllar açısından zengin beslenmenin bazı kanser türlerine karşı potansiyel olarak koruyucu olduğunu vurgulayan halk sağlığı önerilerini destekler niteliktedir. Bu derlemede kanser patogenezinde alkilresorsinollerin rolünü incelemek ve alkilresorsinoller ile kanser arasındaki ilişkiyi aydınlatmak amaçlanmıştır.

Anahtar kelimeler: Tam tahıllar, alkilresorsinoller, kanser

\section{ABSTRACT}

Whole-grain foods are considered as foods with health-protective effects due to the dietary fiber, minerals, vitamins, and phytochemicals in their composition. Alkylresorcinol compounds, which are amphiphilic phenolic lipids found in the structure of whole-grains, have been a subject that has been emphasized in recent years. Especially in vitro studies, it is stated that alkylresorcinols have various physiological and biological activities such as antimicrobial, antioxidant, affecting membrane phospholipid activity and enzyme activity, and inhibit tumorigenesis. It is stated that the phenolic ring and alkyl chain in the structure of alkylresorcinols are important for inhibiting the proliferation of human cancer cells. Studies have shown that alkylresorcinols may have an important role in the pathogenesis of cancer with their ability to affect the

1. İletişim/Correspondence: Bandırma Onyedi Eylül Üniversitesi Sağlık Bilimleri Fakültesi Beslenme ve Diyetetik Bölümü, Balıkesir, Türkiye

E-posta: nurselsahin@bandirma.edu.tr • ๑ https://orcid.org/0000-0001-9045-4177
2. Gazi Üniversitesi Sağllk Bilimleri Fakültesi Beslenme ve Diyetetik Bölümü, Ankara, Türkiye • • ㄴ https://orcid.org/0000-0003-0197-1573 
inhibition of some enzymes and genotoxicity, antioxidant activity, and cytotoxic effects on cancer cell lines. It is stated that high-concentration of alkylresorcinols provide inhibition of human colon, breast, lung, ovarian, prostate, and hepatic cancer cell lines and are considered as highly cytotoxic agents for these cancer types. In addition, it is thought that alkylresorcinols have an important mechanism in the prevention of testosterone and estradiol-dependent cancers by affecting the synthesis of sex hormones. However, there is insufficient evidence about the relation of alkylresorcinols with cancer risk. Establishing safe concentrations and acceptable daily intakes for alkylresorcinols with future studies will provide clearer information. However, the potential role of alkylresorcinols in cancer development supports public health recommendations emphasizing that diets rich in whole-grains are potentially protective against some types of cancer. In this review, it was aimed to examine the role of alkylresorcinols in the pathogenesis of cancer and to elucidate the relationship between alkylresorcinols and cancer.

Keywords: Whole-grains, alkylresorcinols, cancer

\section{GíRIŞ}

Kanser gelişiminde risk faktörleri temel olarak genetik, kronik enfeksiyonlar, karsinojen maddelere maruziyet veya hormon dengesizliği gibi bireysel ve çevresel özellikler veya alkol ve sigara kullanımı, fiziksel aktivite ve beslenme gibi yaşam tarzıyla ilişkilidir (1). Özellikle tüm risk faktörleri dikkate alındığında sağlıksız beslenmenin kanser gelişimini \%30-35 oranında arttırdığı belirtilmektedir (2). Düşük posa alımı, yüksek kırmızı et tüketimi, omega-3 ve omega-6 yağ asiti alımındaki dengesizlik ve antioksidan içerikli besinlerin az tüketilmesi gibi beslenme alışkanlıklarının kanser riskini artırdığ bilinmektedir. Öte yandan, yüksek miktarda meyve ve sebze tüketimi kanser riskini azaltabilmektedir. Bilindiği gibi meyve ve sebzelerin bileşiminde diyet posası, selenyum, folik asit, klorofil ve karotenoidler (alfa-karoten, beta-karoten, laykopen, lutein, kriptoksantin) gibi antioksidan ögeler bulunmaktadır (3). Antioksidan içeriği yüksek olan besinlerin tüketilmesi, insülin büyüme faktörü (IGF-1), nükleer transkripsiyon faktörü (NF- $\kappa B$ ), sitokrom P450 enzim sistemi, reaktif oksijen türleri (ROS) ve mitojenle aktifleştirilen protein kinazların (MAP-kinazlar) aracılık ettiği sinyalleşme gibi bir dizi fizyolojik ve patolojik süreci etkileyerek kanser patogenezinde önemli rol oynamaktadır $(4,5)$.

Tam tahıllı besinler, sağlığı koruyucu etkilere sahip diyet bileşenlerinden biri olarak kabul edilmektedir.
Özellikle son yirmi yllda, tam tahılların ve diyet fitoöstrojenlerinin tüketiminin üzerinde durulması ile birlikte fonksiyonel besin üretimine yönelik araştırmalara ilgi de artmıştır (6). Diyet posası, kükürtlü aminoasitler, lignin, oligosakkaritler, mineraller, vitaminler, polifenoller (örneğin; fenolik asitler, flavonoidler, lignanlar), fitosteroller ve diğer biyoaktif bileşiklerden zengin olan tam tahıllar, sağlığa olumlu etkileri olan fenolik lipitleri de içermektedir. $\mathrm{Bu}$ fenolik lipitlerden biri olan alkilresorsinoller; antimikrobiyal, antimutajenik ve antioksidan olmak üzere çeşitli biyolojik özelliklere sahiptir ve tümörogenez ile ilişkilendirilmektedir $(7,8)$. Ayrıca insan kanser hücre hatlarının büyümesinin önlenmesi ve inhibisyonu için gözlemsel ve in vitro çalışmalarda potansiyel rolü olduğu bildirilmiştir (9). $\mathrm{Bu}$ derlemenin amacı ise güncel literatür doğrultusunda, kanser patogenezinde alkilresorsinollerin rolünü incelemek ve alkilresorsinoller ile kanser arasındaki ilişkiyi aydınlatmaktır.

\section{Alkilresorsinollerin Yapısı ve Kaynakları}

Alkilresorsinoller, genellikle 17-25 karbon birimi arasında değişen uzun bir alkil zincirine sahip 1,3-dihidroksi-5-alkil-benzen türevleri olan fenolik lipitlerdir. Bir polar dihidroksibenzen halkası ve bir hidrofobik alkil zincirinin bu kombinasyonu, alkilresorsinollere amfifilik özellik sağlamaktadır. 
$\mathrm{Bu}$ özelliğin, alkilresorsinollerin herhangi bir biyoaktivitesi için temel olabileceği belirtilmektedir (10).

Alkilresorsinoller, yă asitlerine benzer bir şekilde alkil zincirlerinin uzunluğuna göre adlandırılmaktadır. On yedi karbonlu uzun bir alkil zincirine (heptadesilresorsinol) sahip bir alkilresorsinol, genellikle C17:0 veya AR17:0 olarak gösterilmektedir (10). Şekil 1'de gösterildiği gibi homologlar C17:0, C19:0, C21:0, C23:0 ve C25:0’dır (11).

Alkilresorsinol bileşikleri bazı bitkiler, böcekler, mantarlar, algler, yosunlar, balçık küfleri, deniz süngerleri ve bazı bakterilerde bulunmaktadır (12). Bitkiler arasında ise tam tahıl veya kepek fraksiyonlarında bulunduğu tespit edilmiştir. Özellikle çavdar, buğday taneleri ve daha az miktarlarda arpada, testanın dış kütikulasına ve perikarpın iç kütikulasına dağılmıştır. Tam buğday ve çavdar ürünlerinin dış kısımlarında yüksek konsantrasyonlarda (200-4000 $\mu \mathrm{g} / \mathrm{g}$ kuru madde) ve rafine un veya ürünlerinde ise düşük konsantrasyonlarda (40-280 $\mu \mathrm{g} / \mathrm{g}$ kuru madde) bulunmaktadır $(11,13)$.

Besinlerin alkilresorsinol içeriğini ve homolog oranlarını, tahılın türü, coğrafi bölge, toprak bileşimi, gübreleme ve yetiştirme gibi çeşitli çevresel faktörler etkilemektedir (14). Alkilresorsinollerin konsantrasyonu, tahıl tanesinin tipine bağlı olarak değişmektedir. Buğday ve makarnalık buğday gibi tahıl taneleri arasında alkilresorsinoller açısından en zengin besin çavdardır (8). Örneğin; çavdar yaklaşık

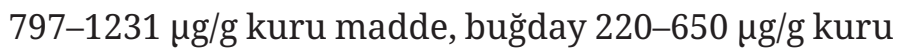
madde ve arpa 40-110 $\mu \mathrm{g} / \mathrm{g}$ kuru madde alkilresorsinol içermektedir (15). Ayrıca tahıllarda C17:0/C21:0 oranı, tam tahılların kaynağını ayırt etmek için kullanılırken 0.1'e yakın bir oran tam tahıllı buğdayı, 1.0'a yakın bir oran ise tam tahıllı çavdarı yansıtmaktadır (16). Bunun yanı sıra tahıllara uygulanan öğütme, pişirme, fermantasyon gibi işlemler, tahıl matrisinin parçalanması ve nişasta granüllerinin jelatinleşmesi yoluyla tahıl tanelerinin besin içeriğini değiştirirken alkilresorsinol konsantrasyonunu da etkilemektedir (6). Bu noktada, C21:0/C19:0 oranı buğdayın tam buğday mı yoksa tam buğday ürünü mü olduğunu belirlemek için kullanılabilmektedir (13). Ayrıca, tahıl tanelerinin yüksek sıcaklıkta işlenmesi, denatürasyon ve bozunmaya bağlı olarak tahılların alkilresorsinol içeriğini azaltmaktadır (6).

\section{Alkilresorsinollerin Metabolizması}

Hayvanveinsançalışmaları, alkilresorsinollerinbüyük ölçüde ince bağırsakta emildiğini ve idrarla atılmadan önce metabolize edildiğini göstermiştir (8). Landberg et al. (17) tarafindan önerilen mekanizmaya (Şekil 2) göre alkilresorsinol bileşikleri ince bağırsaktan emilir. Emilimin hücresel mekanizmalarını açıklayan net bir kanıt olmamakla birlikte bireyler arasında değiştiği ve alım seviyesine bağlı olduğu belirtilmektedir. Daha kısa alkil zinciri homologlarının, daha uzun alkil zincirine sahip olanlara göre daha büyük ölçüde emildiği bildirilmiştir (8). Olası mekanizmada, alkilresorsinol bileşiklerinin şilomikronlar ile \begin{tabular}{lccc} 
& \\
\hline 5-n-Heptadesilresorsinol & $\mathrm{C} 17: 0$ & $\mathrm{R}$ & Molekül ağırlığı (g/mol) \\
5-n-Nonadesilresorsinol & $\mathrm{C} 19: 0$ & $\mathrm{C}_{17} \mathrm{H}_{35}$ & 348 \\
5-n-Heneikosilresorsinol & $\mathrm{C} 21: 0$ & $\mathrm{C}_{19} \mathrm{H}_{39}$ & 376 \\
5-n-Trikosilresorsinol & $\mathrm{C} 23: 0$ & $\mathrm{C}_{21} \mathrm{H}_{43}$ & 404 \\
5-n-Pentakosilresorsinol & $\mathrm{C} 25: 0$ & $\mathrm{C}_{23} \mathrm{H}_{47}$ & 432 \\
\hline Selit & $\mathrm{C}_{25} \mathrm{H}_{51}$ & 460 \\
\hline
\end{tabular}

Şekil 1. Alkilresorsinollerin kimyasal yapıları (11) 
lenfatik sisteme taşındığı belirtilmektedir. Ayrıca bileşiklerin taşınma sırasında yüksek yoğunluklu lipoprotein (HDL), düşük yoğunluklu lipoprotein (LDL) ve çok düşük yoğunluklu lipoprotein (VLDL) fraksiyonlarına doğrudan emilebildiği ve daha sonra lipoproteinlerden eritrosit membranlarına dağıtıldığı bildirilmiştir (17).

Alkilresorsinollerin yarı ömrünün yaklaşık 5 saat olduğuve dolaşımdan atılımının iki faziçeren tokoferol metabolizmasina benzer şekilde gerçekleştiği belirtilmektedir (17). Faz I'de alkilresorsinoller, sitokrom P450 izoenzim CYP4F2 ile katalize edilen omega-oksidasyon yoluyla alkil kuyruğunun ucuna bir hidroksil grubunun ( $\mathrm{OH}-$ ) eklenmesi ile metabolize edilir. Daha sonra, hidroksil grubu bir karboksilik aside oksitlenir, ardından ardışık $\beta$-oksidasyon gerçekleşir. $\mathrm{Bu}$ reaksiyonların sonucunda alkil zinciri kısalır ve iki ana suda çözünür metabolit olan 3-(3,5-dihidroksifenil)-1-propanoik asit (DHPPA) ve 3,5-dihidroksibenzoik asit (DHBA) açığa çıkar $(8,17)$. Faz II'de ise bu metabolitler, bir polar grup tarafindan ksenobiyotiklere veya endojen bileşiklere kısmen konjuge edilir. Bu aşamada, glukuronid sülfat grupları ve aminoasitlerle konjugasyonun, alkilresorsinol metabolitlerinin üriner atılımını iyileştiren anahtar reaksiyon olduğu belirtilmektedir (18).

Alkilresorsinoller ve metabolitleri kanda ve idrarda ölçülebilmektedir (10). Bu nedenle alkilresorsinoller, insan beslenmesinde büyük yeri olan tahıllardan tam tahıl ve çavdar tüketiminin geçerli biyolojik belirteçleri olarak önerilmektedir. Özellikle DHPPA ve DHBA metabolitlerinin tam tahıllı buğday ve çavdar alımı için biyobelirteçler olduğu öne sürülmüştür (19).

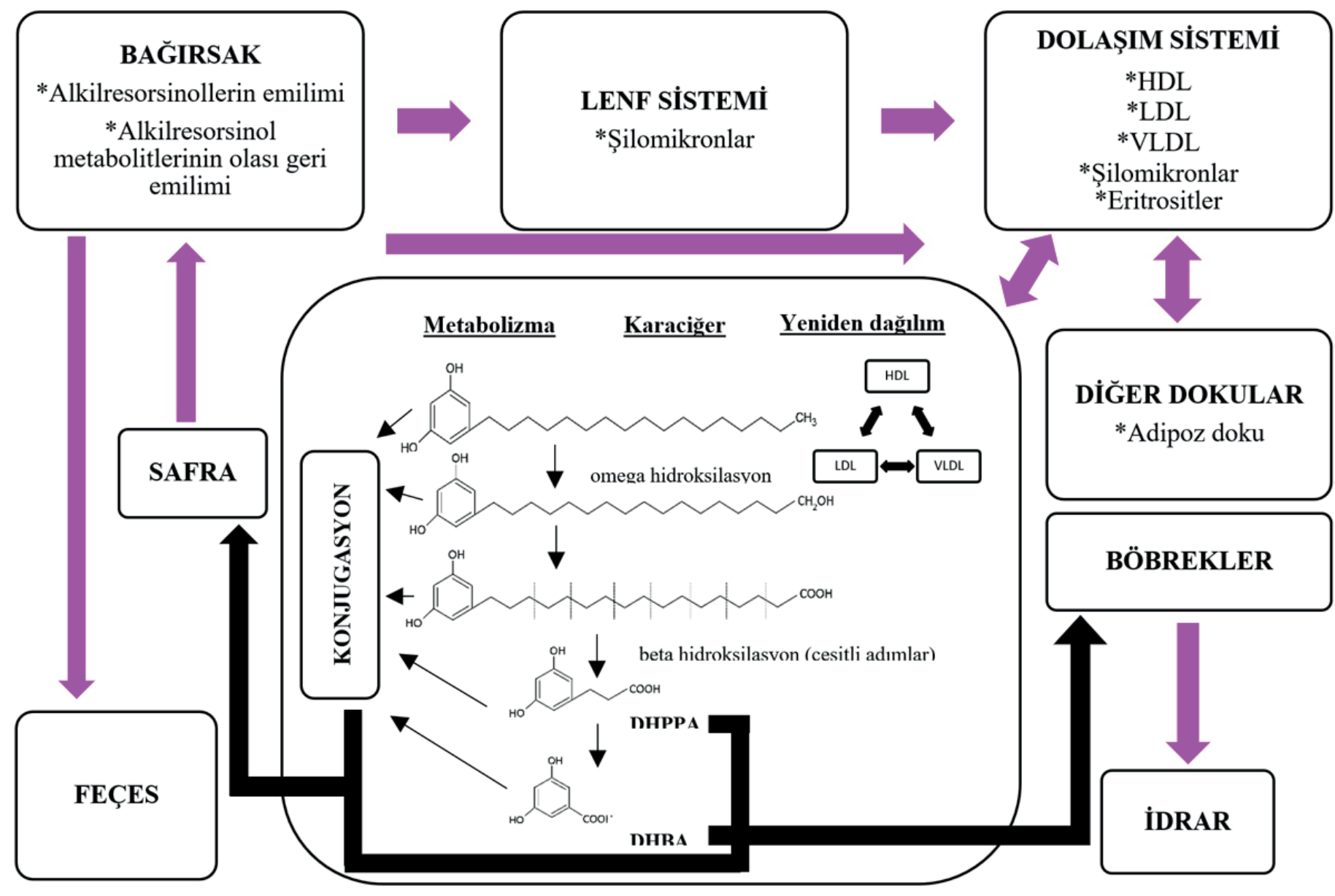

Şekil 2. Alkilresorsinollerin emilimi, dağılımı, metabolizması ve atılımı (17) 


\section{Alkilresorsinollerin Biyolojik Aktiviteleri}

Alkilresorsinoller, amfifilik özellikleri sayesinde geniş bir biyolojik aktivite yelpazesine sahiptirler. Ayrıca alkilresorsinollerin emilimi ve metabolizması da vücuttaki rolleri ile yakından ilgilidir. Yapılarında bulunan alkil zinciri ne kadar uzunsa yağ çözünürlüğü o kadar artmakta olup bu durum, biyolojik aktivitelerini etkilemektedir (10). Bununla birlikte, alkilresorsinollerin biyolojik önemine ilişkin mevcut kanitlar esas olarak in vitro incelemelere dayanmaktadır (9). Bu incelemeler sonrasında, Şekil 3’te belirtildiği gibi alkilresorsinollerin antimikrobiyal (antibakteriyel, anktifunfal), antioksidan, membran fosfolipit aktivitesini ve enzim aktivitesini etkileme ve tümörleri inhibe etme gibi çeşitli fizyolojik ve biyolojik aktivitelere sahip olduğu belirtilmektedir (7).

Alkilresorsinoller, diğer antioksidanlar gibi yapılarında fenolik halka bulundurmalarının yanı sıra lipit peroksidasyonunun zincir reaksiyonunu kırma yetenekleri nedeniyle antioksidan olarak işlev görme
potansiyelinesahiptirler(20).Busayede, alkilresorsinol bileşiklerinin hücresel redoks durumunu modüle edebileceği ve proteinleri, fosfolipitleri, DNA, RNA ve karbonhidratları peroksidasyona karşı koruyabileceği ve timositlerde nükleik asitlerin ve protein sentezinin sinırlanabileceği belirtilmektedir (8,9). Ayrıca, alkilresorsinol bileşiklerinin düşük yoğunluklu lipitlerin $\mathrm{Cu}^{+2}$ iyonu ile indüklenen oksidasyonuna karşı güçlü bir koruyucu etkisi de gözlenmiştir (9).

Alkilresorsinoller, potansiyel olarak enzimler tarafından düzenlenen süreçleri de etkileyebilmektedir. Özellikle lipoksijenazlar, monoamin oksidaz, tirozinaz, $\mathrm{Ca}^{+2}-\mathrm{ATPaz}$, a-glukozidaz, dehidrojenaz, DNA polimeraz $\beta$ ve adipoz dokuda lipaz dahil olmak üzere bazı enzim aktivitelerinin inhibisyonuna neden olmaktadırlar (7,9). Alkilresorsinollerin biyolojik membranlar ve DNA yapısı ile etkileşimlerinin, sitotoksik, antimikrobiyal ve antiparazitik aktiviteleri ile ilgili olduğu belirtilmiştir (21). Ayrıca alkilresorsinoller,

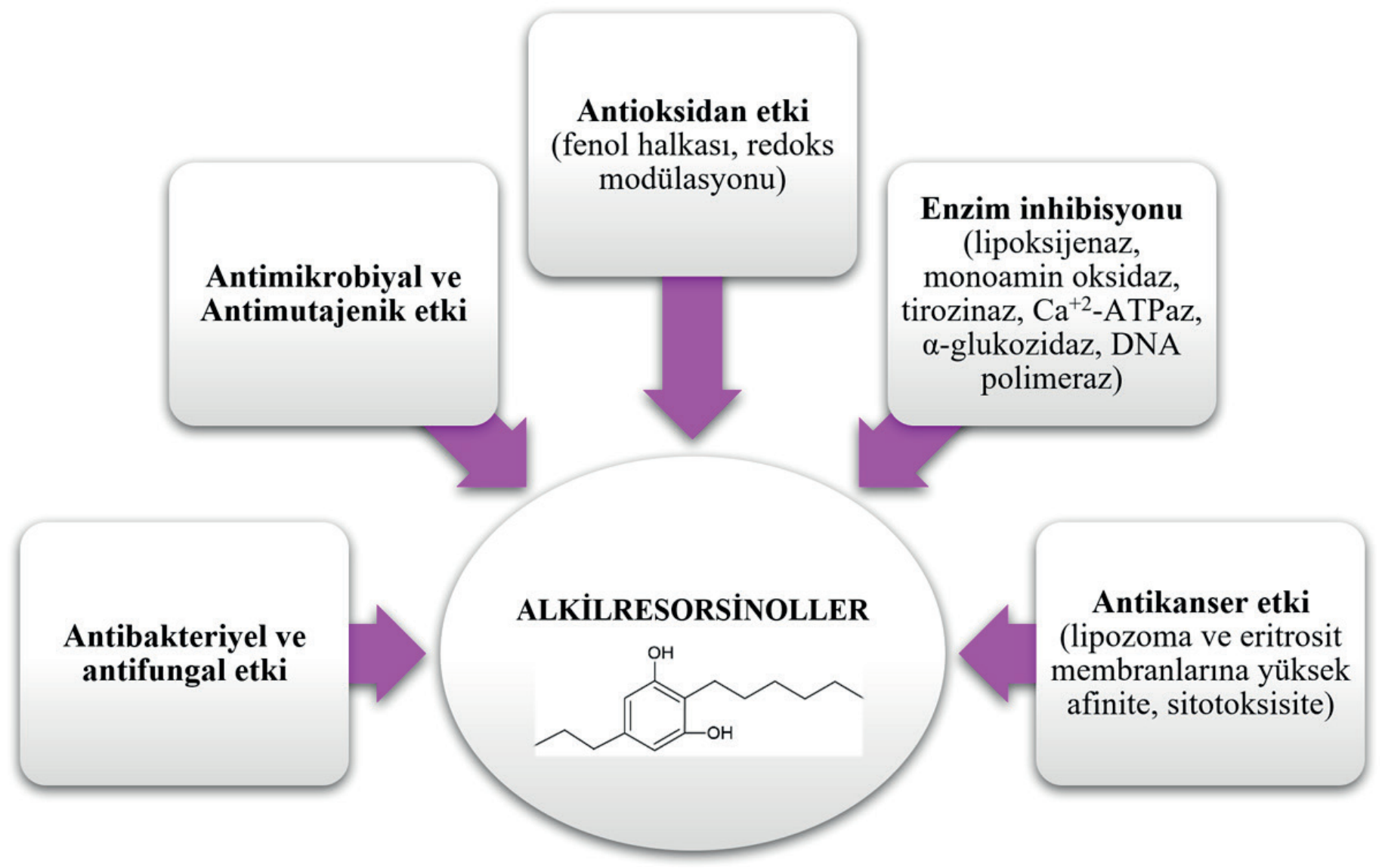

Şekil 3. Alkilresorsinollerin biyolojik aktiviteleri 
lipozom ve eritrosit membranlarına yüksek afinite göstererek iyonlara geçirgenliklerini artırmaktadır (22). Bunun yanı sira yapılarinda bulunan fenol halkası ve alkil zincirlerinin kanser hücrelerinin çoğalmasını azalttığı belirtilmektedir (9).

\section{Alkilresorsinollerin Kanser Patogenezindeki Rolü}

Alkilresorsinoller ile ilgili model çalışmaları, alkilresorsinollerin enzimler tarafından düzenlenen tüm hücresel süreçleri ve genotoksisiteyi etkileyebilen, adiposit lipolizini baskılayan, eritrosit membranlarına yüksek afiniteye gösterebilen, dolaylı antioksidan aktivite gösteren ve kanser hücre hatları üzerinde sitotoksik etki sağlayan aktivitelerinin olduğunu göstermiştir $(23,24)$. Daha ileri analizler, alkilresorsinollerin hasarlı hücrelerin ölüm oranını genotoksisite ile hızlandırabildiğini ve kanser hücrelerinin oluşumunu engelleyebileceğini göstermektedir. $\mathrm{Bu}$ sayede de antikarsinojenik etki sağladığı belirtilmektedir (24). Nitekim alkilresorsinollerin bitkisel kaynağı olan tam tahılların alımının, bağırsak fonksiyonları ve tip 2 diyabet, kardiyovasküler hastalıklar ve bazı kanser türleri gibi yaşam tarzıyla ilgili hastalık riskinin daha düşük olmasıyla ilişkili olduğu bildirilmiştir (25).

In vitro çalışmalar, yüksek alkilresorsinol alımının belirli kanser türleri için yüksek sitotoksik ajanlar olarak kabul edildiğini ve insan kolon, meme, akciğer, over, prostat ve hepatik kanser hücre hatlarının inhibisyonunu sağladığını göstermektedir $(23,26)$. Ancak mevcut literatürün tam tahıl alımının doğru bir şekilde değerlendirilmesiyle ilgili metodolojik sorunlara bağlı olarak alkilresorsinoller ile kanser ilişkisini aydınlatmakta yetersiz kaldığı belirtilmektedir. $\mathrm{Bu}$ derleme kapsaminda ise bazı kanser türlerinde çalışmaların sınırlı olması nedeniyle alkilresorsinoller ile ilgili en çok çalışılan kanser türleri olan kolon, meme, prostat, endometriyal ve over kanserleri üzerinde durulmuştur.

\section{Kolon Kanseri}

Kolon kanserinin önlenmesinde tahıllarda aktif bir bileşen olarak değerlendirilen alkilresorsinollerin, insan kolon kanseri hücre hatları HCT-116 ve HT-29 üzerinde sitotoksik etki sağladığı belirlenmiştir (23). Gözlemlenen sitotoksik etki, daha uzun alkil zincirine (C>17) sahip bileşikler için daha zayıf oranda saptanmıştır. Özellikle C13:0 ve C15:0 homologları, kolon kanseri hücre büyümesinde en etkili inhibitörler olarak belirlenmiştir (23). Benzer şekilde, buğday kepeğinde en bol bulunan $(\% 45,6)$ alkilresorsinol homoloğu C21:0'nin intestinal mikrobiyal metabolit olan bütirat ile birlikte insan kolon kanseri hücrelerinde büyümenin inhibisyonu ve apoptozun indüklenmesinde sinerjistik etki sağladığı rapor edilmiştir (27). On Avrupa ülkesinden bir milyondan fazla kişiden oluşan büyük, çok merkezli bir kohort çalışmada, plazma alkilresorsinol konsantrasyonunun erkeklerde >99 nM ve kadınlarda >84 $\mathrm{nM}$ olması durumunda distal kolon kanserinin insidans hızı oranında (IRR) \%52'lik azalma olduğu belirlenmiştir (28). Benzer şekilde, Knudsen et al. (29) tarafindan yürütülen, 522 vaka ve 562 kontrol grubunun ortalama 4,6 ylllık izlemini kapsayan çalışmada ise plazma alkilresorsinol konsantrasyonlarının distal kolon kanseri insidansı ile ters orantılı olduğu sonucuna varılmıştır. Ayrıca tam tahıl alımı için ölçüm değişkeni olarak besin tüketim sıklığı kullanıldığında, tam tahıl alımı ile herhangi bir kolorektal kanser (kolon, proksimal, distal veya rektum kanseri) arasında hiçbir ilişki gözlenmediği saptanmıştır. Araştırmacılar, tam tahıl tüketiminin belirlenmesinde besin tüketim sıklığı anketleri ile biyobelirteçlerin bir kombinasyon halinde kullanılmasının çalışmaların gücünü artıracağını belirtmiştir (29).

Tam tahılların, cinsiyet hormonuna bağlı kanserler üzerindeki önleyici etkisi kabul edilmiştir ancak aktif bileşenler veya mekanizmalar tam olarak bilinmemektedir (30). Ancak androjenler ve östradiol, 
glukokortikoidler ve mineralokortikoidlerin sentezine yol açan steroidojenik yolların, bir dizi sitokrom P-450 enzimine bağlı olarak gerçekleştiği bilinmektedir. $\mathrm{Bu}$ noktada, alkilresorsinol bileşiklerinin sitokrom P-450 enzim sistemi ile etkileşebileceği belirtilmektedir (17). $\mathrm{Bu}$ nedenle, alkilresorsinollerin cinsiyet hormonu sentezini etkileyerek testesteron ve östradiole bağımlı kanserlerin önlenmesinde önemli bir mekanizmaya sahip olduğu düşünülmektedir (30).

\section{Meme Kanseri}

Tam tahıllar, meme karsinojenezinin her aşamasının yönetiminde iyi tanımlanmış rollere sahip olan biyoaktif fitokimyasalların en temel ve önemli besin kaynağı olarak bilinmektedir. Tam tahılların biyoaktif bileşenlerinin hücre proliferasyonunu inhibe ederek, apoptozu ve hücre döngüsünü regüle ederek, bağışıklık sistemini modüle ederek ve meme tümör hücrelerinin metastazını inhibe ederek antikarsinojenik aktivite gösterdiği rapor edilmiştir (31).

Alkilresorsinollerin ise insan meme kanseri hücresinin büyümesini engelleyebileceğini gösteren birkaç in vitro çalışma bulunmaktadır. Homalomena wendlandii Schott’tan (Areacae) izole edilen beş alkilresorsinol bileşiğinin, meme adenokarsinom hücre hattı MCF-7'nin büyümesini inhibe ettiği gözlenmiştir. Ayrıca alkilresorsinol bileşiklerinin sitostatik adriamisine kıyasla test edilen insan meme (MCF-7), akciğer (H-460), merkezi sinir sistemi (SF-268) kanser hücre hatları üzerinde en az \%800 daha güçlü bir inhibitör etki gösterdiği belirlenmiştir (32). AlMeklafi et al. (33) tarafından yürütülen bir çalışmada ise önemli bir tıbbi bitkiden izole edilen alkilresorsinol bileşiklerinin, insan prostat (PC-3), kolon (HCT116) ve meme kanser hücre hatlarına (MCF-7) karşı en sitotoksik aktiviteyi gösterdiği ve kemoterapik bir ajan olan doksorubisinden daha aktif olduğu bildirilmiştir. Diğer taraftan ise tam tahıllı çavdar ve buğday alımının menopoz sonrası meme kanseri gelişim riski üzerine etkisini inceleyen Danimarka
“Diyet, Kanser ve Sağlık Kohortu”nda besin tüketim sıklığı anketi ile tahmin edilen ve adipoz dokudaki toplam alkilresorsinol konsantrasyonunun meme kanseri gelişim riski ile ilişkili olmadığı sonucuna varılmıştır (34).

\section{Prostat Kanseri}

Alkilresorsinoller ile prostat kanseri arasındaki ilişkiyi inceleyen çalışma sayısı oldukça sınırlıdır. İsveç popülasyonunda yapılan bir çalışmada (1016 vaka, 1817 kontrol), plazma alkilresorsinol metabolitleri ile prostat kanseri riski arasında pozitif bir ilişki saptanmış ancak bu ilişkinin doğrusal olmadığı belirlenmiştir. En düşük risk, orta düzey plazma konsantrasyonlarına sahip erkekler arasında görülmüştür. Orta düzey plazma alkilresorsinol konsantrasyonuna klyasla yüksek plazma alkilresorsinol konsantrasyonu olan erkeklerde ise prostat kanseri riskinin daha fazla [Odds oranı $=1.41$ (1.10-1.80)] olduğu görülmüştür (35). İdrar ve plazma alkilresorsinol metabolitleri DHBA ve DHPPA'yı prostat kanserli hastalarda ve kontrol grubunda araştıran bir çalışmada, plazma DHPPA konsantrasyonu, prostat kanseri grubunda kontrol grubuna göre önemli ölçüde daha yüksek bulunmuştur. Bu farklılığın bir önceki gün çavdar ekmeği alımına bağlı olmadığı ve prostat kanseri olan grupta alkilresorsinol metabolitlerinin metabolizmasında bir bozulma olabileceği bildirilmiştir (36). Bunun yanı sıra buğday kepeğinden izole edilen yedi alkilresorsinol bileşiğinin dördünün, insan prostat adenokarsinomu hücrelerinin (PC3) büyümesine karşı güçlü sitotoksik etkiye sahip olduğu belirlenmiştir. Aynı zamanda alkilresorsinollerin PC3 hücre hattı üzerinde pozitif kontrol klorambusilden daha yüksek sitotoksik etkiler uyguladığı saptanmıştır (24).

\section{Endometriyal ve Over Kanserleri}

Yakın zamanlı bir sistematik derleme kapsamında, antikanser aktiviteleri için doğal veya sentetik alkilresorsinollerin analizi 4 gözlemsel ve 10 in vitro 
çalışma ile değerlendirilmiştir. Bu değerlendirme sonucunda, plazmadaki nanomolar alkilresorsinol konsantrasyonunda distal kolon kanserinde \%52-66 oranında bir azalma olduğunu ancak endometriyal kanser riskinde azalma olmadığı rapor edilmiştir. Ayrıca mikromolar alkilresorsinolkonsantrasyonunda insan kolon, meme, akciğer, merkezi sinir sistemi, adenokarsinom, hepatokarsinom, serviks skuamöz karsinom ve over kanseri hücre hatlarının inhibisyona uğradığı belirtilmiştir (12). Danimarkalı 53-60 yaşları arasındaki postmenopozal kadınlarla yapılan bir vaka-kontrol çalışmasında ise plazma alkilresorsinol bileşikleri konsantrasyonu açısından vaka ve kontrol grupları arasında istatistiksel olarak önemli farklılıkların olmadığı belirlenmiştir. Ayrıca tam tahılların tüketimi ile endometriyal kanser insidansı arasında güçlü bir ilişkinin olmadığı belirtilmiştir (37). Danimarka “Diyet, Kanser ve Sağlık Kohortu”nda 50-64 yaş arası 24418 kadının 217'sinde endometriyal kanser tanısının bulunduğu ve daha yüksek tam tahıl ve diyet posası alımı ile endometriyal kanser insidansı arasında net bir ilişkinin bulunmadığı bildirilmiştir (38). Benzer şekilde, postmenopozal 360 kadının dahil edildiği çalışmada, kontrol grubu ile endometriyal kanser vakaları arasında plazma alkilresorsinol düzeyleri arasında farklılık bulunmamıştır (39). Oncostemon bojerianum'undan izole edilen bir bis-5alkilresorsinol ailesi olan onkostemonoller ile yapılan çalışmada ise DNA polimeraz $\beta$ inhibisyonu yoluyla A2780 over kanseri hücre hattına karşı sitotoksisite gösterdiği bildirilmiştir (40).

\section{SONUÇ VE ÖNERİLER}

Tam tahıllı buğday ve çavdar ürünleri tüketiminin potansiyel biyobelirteci olan alkilresorsinollerin fizyolojik ve patolojik süreçleri etkileyebilen fonksiyonlar gösterdiği birçok çalışmada rapor edilmiştir. İ vitro çalışmalarda, yüksek konsantrasyondaki alkilresorsinoller, özellikle belirli kanser türleri için yüksek sitotoksik ajanlar olarak kabul edilmekte ve kanser hücre hatlarının inhibisyonunu sağlamaktadır. Ayrıca yapısında bulunun fenolik halka ve alkil zincirinin insan kanser hücrelerinin çoğalmasının engellenmesi için önemli olduğu belirtilmektedir. Alkilresorsinoller ile kanser riski ilişkisi hakkında yeterli kanıt bulunmamasına rağmen alkilresorsinollerin kanser gelişimindeki potansiyel rolü, tam tahıllar açısından zengin diyetlerin bazı kanser türlerine karşı potansiyel olarak koruyucu olduğunu vurgulayan halksağlığı önerilerini destekler niteliktedir. Özellikle yapılan çalışmalar, tam tahıllı besinlerin tüketimini vurgulayan ve antioksidan ögelerden zengin olan Akdeniz tipi beslenme gibi sürdürülebilir diyet modellerinin önemini artırmaktadır. Gelecekte yapılacak in vivo klinik çalışmalar ile alkilresorsinollerin kanserde kullanımı için güvenli konsantrasyonlar ve kabul edilebilir günlük alım miktarları oluşturulması daha net bilgiler sağlayacaktır.

Yazarlık katkısı - Author contributions: Çalışmanın tasarımı: NŞ, GA; İlgili literatürün taranması: NŞ; Makale taslağınin oluşturulmast: NŞ, GA; İçerik için eleştirel gözden geçirme: GA, NŞ; Yayinlanacak versiyonun son onayl: NŞ, GA. - Study design: NS, GA; Literature review: NS; Draft preparation: NS, GA; Critical review for content: GA, NS; Final approval of the version to be published: NS, GA.

Çıkar çatışması - Conflict of interest: Yazarlar çıkar çatışması olmadığını beyan ederler. - The authors declare that they have no conflict of interest.

\section{KAYNAKLAR}

1. Mentella MC, Scaldaferri F, Ricci C, Gasbarrini A, Miggiano GAD. Cancer and Mediterranean Diet: A review. Nutrients. 2019;11(9):2059.

2. Key TJ, Allen NE, Spencer EA, Travis RC. The effect of diet on risk of cancer. The Lancet. 2002;360(9336):861-8.

3. Divisi D, Di Tommaso S, Salvemini S, Garramone M, Crisci R. Diet and cancer. Acta Bio-Medica: Ateneo Parmense. 2006;77(2):118-23.

4. Bose S, Allen AE, Locasale JW. The molecular link from diet to cancer sell metabolism. Mol Cell. 2020;78(6):103444.

5. Androutsopoulos VP, Papakyriakou A, Vourloumis D, Tsatsakis AM, Spandidos DA. Dietary flavonoids in cancer therapy and prevention: substrates and inhibitors of cytochrome P450 CYP1 enzymes. Pharmacol Ther. 2010;126(1):9-20. 
6. Luthria DL, Lu Y, John KM. Bioactive phytochemicals in wheat: Extraction, analysis, processing, and functional properties. J Funct Foods. 2015;18:910-25.

7. Luís Â, Domingues F, Duarte AP. Biological properties of plant-derived alkylresorcinols: Mini-review. Mini Rev Med Chem. 2016;16(11):851-4.

8. Ross AB, Kamal-Eldin A, Åman P. Dietary alkylresorcinols: absorption, bioactivities, and possible use as biomarkers of whole-grain wheat-and rye-rich foods. Nutr Rev. 2004;62(3):81-95.

9. Kruk J, Aboul-Enein B, Bernstein J, Marchlewicz M. Dietary alkylresorcinols and cancer prevention: A systematic review. Eur Food Res Technol. 2017;243(10):1693-710.

10. Ross AB. Alkylresorcinols. In: Johnson J, Wallace TC editors. Whole Grains and their Bioactives: Composition and Health. 1st ed. 2019. p. 393-406.

11. Landberg R, Kamal-Eldin A, Andersson A, Vessby B, Aman P. Alkylresorcinols as biomarkers of wholegrain wheat and rye intake: plasma concentration and intake estimated from dietary records. Am J Clin Nutr. 2008;87(4):832-8.

12. Kozubek A, Tyman JH. Resorcinolic lipids, the natural non-isoprenoid phenolic amphiphiles and their biological activity. Chem Rev. 1999;99(1):1-26.

13. Ross $A B$, Kochhar S. Rapid and sensitive analysis of alkylresorcinols from cereal grains and products using HPLC-Coularray-based electrochemical detection. J Agric Food Chem. 2009;57(12):5187-93.

14. Gunenc A, HadiNezhad M, Tamburic-Ilincic L, Mayer PM, Hosseinian F. Effects of region and cultivar on alkylresorcinols content and composition in wheat bran and their antioxidant activity. J Cereal Sci. 2013;57(3):405-10.

15. Frølich W, Åman P, Tetens I. Whole grain foods and health-a Scandinavian perspective. Food Nutr Res. 2013;57(1):18503.

16. Chen Y, Ross AB, Åman P, Kamal-Eldin A. Alkylresorcinols as markers of whole grain wheat and rye in cereal products. J Agric Food Chem. 2004;52(26):8242-6.

17. Landberg R, Marklund M, Kamal-Eldin A, Åman P. An update on alkylresorcinols-Occurrence, bioavailability, bioactivity and utility as biomarkers. J Funct Foods. 2014;7:77-89.

18. Bordiga M, Locatelli M, Travaglia F, Arlorio M, Reyneri A, Blandino M, et al. Alkylresorcinol content in whole grains and pearled fractions of wheat and barley. J Cereal Sci. 2016;70:38-46.

19. Söderholm PP, Lundin JE, Koskela AH, Tikkanen MJ, Adlercreutz HC. Pharmacokinetics of alkylresorcinol metabolites in human urine. Br J Nutr. 2011;106(7):10404.
20. Elder AS, Coupland JN, Elias RJ. Antioxidant activity of a winterized, acetonic rye bran extract containing alkylresorcinols in oil-in-water emulsions. Food Chem. 2019;272:174-81.

21. Stasiuk M, Kozubek A. Biological activity of phenolic lipids. Cell Mol Life Sci. 2010;67(6):841-60.

22. Kozubek A. The effect of 5-(n-alk (en) yl) resorcinols on membranes. I. Characterization of the permeability increase induced by 5-(n-heptadecenyl) resorcinol. Acta Biochim Pol. 1987;34(4):357-67.

23. Zhu Y, Soroka DN, Sang S. Synthesis and inhibitory activities against colon cancer cell growth and proteasome of alkylresorcinols. J Agric Food Chem. 2012;60(35):8624-31.

24. Liu L, Winter KM, Stevenson L, Morris C, Leach DN. Wheat bran lipophilic compounds with in vitro anticancer effects. Food Chem. 2012;130(1):156-64.

25. Liu J, Yu LL, Wu Y. Bioactive Components and Health Beneficial Properties of Whole Wheat Foods. J Agric Food Chem. 2020;68(46):12904-15.

26. Vila-Luna SE, Moo-Puc RE, Torres-Tapia LW, PerazaSánchez SR. New metabolites with cytotoxic and antiproliferative activities isolated from Bonellia macrocarpa. Phytochem Lett. 2017;19:121-5.

27. Zhao Y, Shi L, Hu C, Sang S. Wheat bran for colon cancer prevention: the synergy between phytochemical alkylresorcinol C21 and intestinal microbial metabolite butyrate. J Agric Food Chem. 2019;67(46):12761-9.

28. Kyrø C, Olsen A, Landberg R, Skeie G, Loft S, Åman P, et al. Plasma alkylresorcinols, biomarkers of wholegrain wheat and rye intake, and incidence of colorectal cancer. J Natl Cancer Inst. 2014;106(1):djt352.

29. Knudsen MD, Kyrø C, Olsen A, Dragsted LO, Skeie G, Lund E, et al. Self-reported whole-grain intake and plasma alkylresorcinol concentrations in combination in relation to the incidence of colorectal cancer. Am J Epidemiol. 2014;179(10):1188-96.

30. Oskarsson A, Ohlsson A. Suppressed Sex Hormone Biosynthesis by Alkylresorcinols: A Possible Link to Chemoprevention. Nutr Cancer. 2016;68:1-10.

31. Cho K, Lee CW, Ohm JB. In vitro study on effect of germinated wheat on human breast cancer cells. Cereal Chem. 2016;93(6):647-9.

32. Sánchez LA, Olmedo D, López-Pérez JL, Williams TD, Gupta MP. Two new alkylresorcinols from Homalomena wendlandii and their cytotoxic activity. Nat Prod Commun. 2012;7(8):1934578X1200700820.

33. Al-Mekhlafi NA, Shaari K, Abas F, Kneer R, Jeyaraj EJ, Stanslas J, et al. Alkenylresorcinols and cytotoxic activity of the constituents isolated from Labisia pumila. Phytochemistry. 2012;80:42-9. 
34. Wu H, Kyrø C, Tjønneland A, Boll K, Olsen A, Overvad $\mathrm{K}$, et al. Long-term whole grain wheat and rye intake reflected by adipose tissue alkylresorcinols and breast cancer: a case-cohort study. Nutrients. 2019;11(2):465.

35. Drake I, Sonestedt E, Gullberg B, Bjartell A, Olsson H, Adlercreutz $\mathrm{H}$, et al. Plasma alkylresorcinol metabolites as biomarkers for whole-grain intake and their association with prostate cancer: A Swedish nested case-control study. Cancer Epidemiol Biomarkers Prev. 2014;23(1):73-83.

36. Meija L, Krams I, Cauce V, Samaletdin A, Söderholm P, Meija R, et al. Alkylresorcinol metabolites in urine and plasma as potential biomarkers of rye and wheat fiber consumption in prostate cancer patients and controls. Nutr Cancer. 2015;67(2):258-65.
37. Olsen A, Landberg R, Aman P, Kamal-Eldin A, Christensen J, Johnsen NF, et al. Plasma levels of alkylresorcinols and incidence of endometrial cancer. Eur J Cancer Prev. 2010;19(1):73-7.

38. Aarestrup J, Kyrø C, Christensen J, Kristensen M, Würtz AM, Johnsen NF, et al. Whole grain, dietary fiber, and incidence of endometrial cancer in a Danish cohort study. Nutr Cancer. 2012;64(8):1160-8.

39. Landberg R, Kamal-Eldin A, Aman P, Christensen J, Overvad K, Tjønneland A, et al. Determinants of plasma alkylresorcinol concentration in Danish postmenopausal women. Eur J Clin Nutr. 2011;65(1):94-101.

40. Schmidt M, Sartor BE, Bedoya S, Cannon J. Method development for the synthesis of novel bis-5alkylresorcinols. In: Southern California Conferences for Undergraduate Research Physical Sciences. 2017;4;Nov 18. 